\title{
Prinsip Penetapan Sanksi bagi Pelanggaran Etik Kedokteran
}

\author{
Anna Rozaliyani ${ }^{\mathrm{I}, 2}$, Putri Dianita Ika Meilia ${ }^{\mathrm{I}, 3}$, Nurfanida Librianty ${ }^{\mathrm{T}, 4}$ \\ ${ }^{1}$ Majelis Kehormatan Etik Kedokteran Pengurus Besar Ikatan Dokter Indonesia \\ ${ }_{2}^{2}$ Departemen Parasitologi Klinik, Fakultas Kedokteran Universitas Indonesia/Rumah Sakit Cipto Mangunkusumo, Jakarta \\ ${ }^{3}$ Instalasi Kedokteran Forensik dan Pemulasaraan Jenazah, Rumah Sakit Umum Pusat Persahabatan, Jakarta \\ ${ }^{4}$ Departemen Pulmonologi dan Kedokteran Respirasi, Fakultas Kedokteran Universitas Indonesia/Rumah Sakit Umum Pusat Persahabatan
}

\author{
Kata Kunci \\ Dokter, etik, pelanggaran, sanksi \\ Korespondensi \\ contact@ilmiah.id \\ Publikasi \\ (C) $2018 \mathrm{JEKI} /$ ilmiah.id \\ DOI \\ I0.26880/jeki.v2i..II \\ Tanggal masuk: 22 Februari 2018 \\ Tanggal ditelaah: 10 Maret 2018 \\ Tanggal diterima: II Maret 2018 \\ Tanggal publikasi: I9 Maret 2018
}

\begin{abstract}
Abstrak
Sebagai profesi yang menjunjung tinggi hubungan luhur dengan pasien, dokter wajib menjunjung tinggi nilai-nilai etik yang terkandung dalam Kode Etik Kedokteran Indonesia (KODEKI) tahun 20I2. Pelanggaran etik kedokteran perlu disikapi dengan pemberian sanksi yang sesuai, yang bertujuan sebagai pembinaan terhadap teman sejawat. Prinsip, tujuan, dan ketentuan pemberian sanksi tersebut diatur oleh Majelis Kehormatan Etik Kedokteran PB IDI.
\end{abstract}

\begin{abstract}
As a profession which upholds noble relationship with patients, doctors are obliged to uphold the ethical values as dictated in the Indonesian Medical Code of Ethics (KODEKI) 20I2. Medical ethical violations have to be addressed by appropriate sanctions, aimed at educating peers. The principles, objectives, and regulations of such sanctions are governed by the Medical Ethics Council of Honors of Indonesian Doctor's Association.
\end{abstract}

\section{PENDAHULUAN}

Hubungan dokter dengan pasien adalah hubungan luhur berdasarkan prinsip kepercayaan yang harus didukung sikap profesional. Kaidah untuk hubungan tersebut diatur dalam Kode Etik Kedokteran Indonesia (KODEKI) tahun 2012. Namun, pelanggaran etik kedokteran masih kerap terjadi, mulai dari masalah empati atau komunikasi, konflik etikolegal antarbidang kedokteran, hingga konflik kepentingan, termasuk peran ganda sebagai dokter dan advokat, ${ }^{2}$ atau dokter yang ikut mempromosikan produk tertentu. ${ }^{3}$

Pelanggaran tersebut perlu disikapi dengan pemberian sanksi yang sesuai. Tujuan pemberian sanksi bagi pelanggar etik kedokteran sejatinya bersifat pembinaan terhadap teman sejawat sehingga mereka menyadari kekeliruan yang dilakukan tanpa merasa direndahkan martabatnya. Dalam artikel ini akan dibahas tentang prinsip, tujuan, dan ketentuan pemberian sanksi serta peran Majelis Kehormatan Etik Kedokteran Pengurus Besar Ikatan Dokter Indonesia (MKEK PB IDI) dalam penegakan etik kedokteran di Indonesia.

Penelusuran literatur dilakukan terhadap ketentuan yang terdapat dalam UndangUndang Praktik Kedokteran tahun 2004, Kode Etik Kedokteran Indonesia (KODEKI), serta literatur terkait lainnya melalui pencarian pangkalan data elektronik. Selain itu, dilakukan wawancara mendalam terhadap beberapa pakar etik kedokteran di Indonesia untuk memperoleh wawasan lebih mendalam terkait pemberian sanksi yang mendidik. 


\section{HASIL DAN PEMBAHASAN}

\section{Prinsip Sanksi}

Hal pertama yang harus diingat bahwa sanksi yang diberikan adalah hasil keputusan manusia dan bukan semata reaksi sebabakibat dari alam, sehingga harus ada individu atau institusi yang memiliki kuasa yang lebih dominan dibandingkan pelaku. Sanksi dapat berupa pencabutan atau pembekuan hak pelaku yang bersifat sementara. Berat ringannya sanksi biasanya ditentukan pemilik kuasa berdasarkan kerugian atau beban yang dialami pihak korban. Dalam hal ini syarat pemberian sanksi adalah dianggap bersalah oleh pemilik kuasa, meskipun dapat saja bukan benar-benar bersalah pada kenyataannya. Hal itu menyebabkan sanksi dapat menjadi salah satu buah kekuasaan yang dapat disalahgunakan. ${ }^{4}$

\section{Tujuan Pemberian Sanksi ${ }^{5}$}

Secara umum, pemberian sanksi memiliki empat tujuan utama, yaitu:

1. Sebagai hukuman bagi orang yang melakukan pelanggaran

Pelanggaran terhadap suatu aturan tentunya memiliki konsekuensi tertentu. Bentuk dan beratnya hukuman harus disesuaikan dengan beratnya pelanggaran yang terjadi dan dampak yang dihasilkan

2. Sebagai sarana untuk mendidik dan melakukan rehabilitasi

Agar dapat memberikan manfaat di kemudian hari, perlu diberikan umpan balik kepada pihak yang melakukan pelanggaran sehingga pelaku memahami dengan tepat kesalahan yang dilakukannya sekaligus mengetahui cara menghindari terjadinya pengulangan pelanggaran

3. Untuk melindungi masyarakat

Pemberian sanksi perlu dilakukan untuk melindungi masyarakat terhadap dampak negatif pelanggaran aturan. Integritas kelompok yang memiliki aturan tersebut juga perlu dilindungi dengan mencegah pelanggaran yang dapat merusak harkat profesi
4. Sebagai panutan bagi anggota lain dalam kelompok yang sama dan terikat aturan yang sama.

Pemberian sanksi bagi pelanggar diharapkan dapat mencegah pelanggaran berulang oleh anggota lain dalam kelompok, sekaligus mengingatkan tentang norma atau peraturan yang tidak boleh dilanggar.

\section{Ketentuan Pemberian Sanksi}

Pemberian sanksi secara umum dilakukan dengan tiga tahap: ${ }^{6}$

Tahap pertama adalah merumuskan tujuan sanksi yang diberikan. Sanksi harus bertujuan mendidik pelaku dengan nilai yang sesuai, mempertimbangkan kondisi pelaku dan masyarakat secara luas. Pemberian sanksi juga harus disertai penjelasan dan penegasan agar pelaku mengerti bahwa terdapat peraturan yang harus ditaati. Sanksi juga harus diberikan secara spesifik dan menghindari pertimbangan tidak relevan yang dapat mengalihkan perhatian dari pelanggaran etik itu sendiri (non-issue).

Tahap kedua adalah menentukan berat ringannya sanksi berdasarkan beberapa pertimbangan:jenis pelanggaran, beratringannya pelanggaran berdasarkan konsensus atau ketentuan yang berlaku, riwayat pelanggaran, dan faktor-faktor penyerta lain. Selain itu harus dilakukan upaya menyeimbangkan antara sanksi aktif dan pasif. Jenis pelanggaran yang dimaksud adalah pemberian sanksi dengan penjelasan dan penegasan terhadap tindakan yang dibuat, bukan terhadap suatu klausul peraturan semata, misalnya "Anda melanggar karena Anda mencuri" bukan sekedar mengatakan "Anda melanggar peraturan nomor 5" tanpa menjelaskan lebih rinci isi peraturan tersebut. Hal itu bertujuan agar pelaku mengerti jenis pelanggaran dan dampak yang mungkin timbul, bukan hanya menyebutkan klausul/peraturan pelanggaran yang terjadi. Berat ringannya pelanggaran ditentukan berdasarkan konsensus atau keputusan pihak berwenang dengan mempertimbangkan berbagai kondisi. Keributan yang ditimbulkan seseorang di perpustakaan memiliki sanksi berbeda dibandingkan dengan keributan di kelas. Bermain telepon genggam pada saat 
pemeriksaan imigrasi memiliki dampak berbeda dibandingkan dengan bermain telepon genggam di bioskop. Riwayat pelanggaran berkaitan dengan jumlah pelanggaran sebelumnya yang pernah dilakukan pelaku, baik pelanggaran serupa maupun tidak. Faktor penyerta yang perlu dipertimbangkan misalnya niat, keadaan individu pada saat kejadian, tingkat kemudahan kerjasama pelaku pada proses peradilan, pengaruh alkohol atau obat-obatan terlarang. Sanksi juga perlu diberikan dengan mempertimbangkan kombinasi sanksi pasif (berupa pembekuan hak) maupun aktif (berupa pemberian kewajiban) yang dapat memberikan dampak positif terhadap pelaku dan masyarakat sekitarnya.

Tahap ketiga adalah pelaksanaan sanksi yang konkrit dan terawasi. Sanksi yang telah diberikan harus dievaluasi bila terdapat pengulangan pelanggaran atau hambatan ketika sanksi sedang dijalankan.

\section{Penegakan Etik Kedokteran di Indonesia}

Etika kedokteran Indonesia merupakan sekumpulan nilai dan moralitas profesi kedokteran yang tercantum dalam KODEKI, fatwa-fatwa etik, pedoman dan kesepakatan etik lainnya dari Ikatan Dokter Indonesia (IDI). Etika kedokteran secara umum dibuat untuk meningkatkan profesionalisme, pengetahuan, pemahaman, penghayatan, pengamalan kaidah dasar bioetika dan etika kedokteran dalam profesinya sebagai seorang dokter. Secara khusus, etika kedokteran dirumuskan untuk menjaga keluhuran profesi, meredam konflik etikolegal, penjeraan sekunder perilaku kurang etis, dan menjaga hubungan antara dokter dan pasien sebagai hubungan kepercayaan.

\section{Peran MKEK dalam Penegakan Etika Kedokteran di Indonesia ${ }^{7}$}

Penegakan, pengawasan, dan perumusan etik praktik kedokteran dilakukan oleh MKEK sebagai badan otonom IDI yang dibagi menjadi tingkat pusat, wilayah, dan cabang. Majelis ini memiliki hak untuk menyampaikan pertimbangan pelaksanaan etika kedokteran dan mengusulkan secara lisan atau tertulis, diminta atau tidak diminta kepada pengurus IDI mengenai setiap permasalahan etika kedokteran di wilayah jurisdiksinya masing-masing.

Penetapan kategori berat ringannya kesalahan didasarkan atas kriteria akibat yang ditimbulkan terhadap keselamatan pasien, kehormatan profesi, kepentingan umum, serta itikad baik teradu dalam turut menyelesaikan kasus, motivasi yang mendasari timbulnya kasus, serta situasi lingkungan yang mempengaruhi timbulnya kasus. Selain itu pendapat dan pandangan Biro Hukum, Pembinaan dan Pembelaan Anggota (BHP2A) juga menjadi salah satu pertimbangan.

\section{Mekanisme Pemberian Sanksi sesuai Pedoman Organisasi dan Tata Laksana Kerja (ORTALA) MKEK ${ }^{7}$}

Dalam ORTALA MKEK, pemberian sanksi terhadap dokter terhukum/pelanggar etik dapat berupa penasihatan, peringatan lisan, peringatan tertulis, pembinaan perilaku, pendidikan ulang (re-schooling), hingga pemecatan keanggotaan IDI, baik secara sementara atau pun permanen. Pada umumnya sanksi etik tersebut bersifat pembinaan, kecuali pemecatan keanggotaan yang bersifat permanen atau pencabutan keanggotaan seumur hidup.

Mekanisme pemberian sanksi oleh MKEK diawali dari masuknya pengaduan yang sah, dilanjutkan dengan proses penelaahan kasus yang diadukan. Pada akhir penelaahan, Ketua MKEK menetapkan kelayakan kasus untuk disidangkan oleh majelis pemeriksa yang akan melakukan sidang kemahkamahan hingga tercapai keputusan MKEK. Bila terbukti terdapat bukti pelanggaran etik, maka majelis akan menetapkan sanksi sesuai dengan berat ringannya kesalahan dokter teradu. Pelaksanaan sangsi dilakukan oleh Divisi Pembinaan Etika Profesi MKEK untuk dan atas nama pengurus IDI setingkat.

\section{KESIMPULAN}

Pelanggaran etik kedokteran perlu disikapi dengan pemberian sanksi yang sesuai. Tujuan pemberian sanksi etik sejatinya bersifat pembinaan terhadap teman sejawat. Majelis Kehormatan Etik Kedokteran PB IDI telah 
menetapkan prinsip, tujuan, dan ketentuan pemberian sanksi dalam upaya penegakan etik kedokteran di Indonesia.

\section{KONFLIK KEPENTINGAN}

Tidak ada konflik kepentingan.

\section{REFERENSI}

1. Majelis Kehormatan Etik Kedokteran Indonesia. Kode Etik Kedokteran tahun 2012. Jakarta; 2012.

2. Purwadianto A, Meilia PDI. Tinjauan etis rangkap profesi dokter-pengacara. JEKI. 2017; 1(1): 1-6. doi: 10.26880/jeki.v1i1.2.

3. Prawiroharjo P, Meilia PDI. Dokter beriklan: sebuah tinjauan menurut Kode Etik Kedokteran Indonesia (KODEKI) tahun 2012. JEKI. 2017; 1(1): 13-7. doi: 10.26880/jeki. v1i1.4.

4. Bedau, Adam H, Kelly E. Punishment [internet]. 2015 [diakses 2018 Mar 10]. Diunduh dari: https://plato.stanford.edu/entries/ punishment/.

5. American Speech-language Hearing Association's Board of Ethics. How ASHA's Board of Ethics sanctions individuals found in violation of the code of ethics [internet]. 2016 [diakses 2018 Mar 10]. Diunduh dari: https:// www.asha.org/practice/ethics/sanctions/.

6. Olshak R. A guide for effective sanctioning: From theory to practice. Illinois: Illinois State University. 2008.

7. Purwadianto A, editor. Pedoman organisasi dan tata laksana kerja Majelis Kehormatan Etik Kedokteran. Jakarta: Majelis Kehormatan Etika Kedokteran Ikatan Dokter Indonesia; 2008. 